\title{
Land-Use and Land-Cover Change in Semi-Arid Zone: The Case of Waro-Souloulou Area in Goulbi Maradi Watershed in the Republic of Niger
}

\author{
Issaharou Matchi Issiaka (Corresponding author) \\ School of Environmental Studies, China University of Geosciences \\ No. 388 Lumo Road, Wuhan 430074, Hubei Province, China \\ Tel: 86-159-0710-4245 E-mail: isak82.matchi2@yahoo.fr \\ Yamba Boubacar \\ Geography Department, Faculty of Arts and Human Sciences \\ Abdou Moumouni University of Niamey, Niger \\ E-mail: byamba@refer.ne \\ Yansheng Gu \\ State Key Laboratory of Geobiology and Environmental Geology \\ China University of Geosciences, Wuhan 430074, China \\ E-mail: yansheng_gu@yahoo.com.cn
}

Received: November 23, 2011

Accepted: December 18, $2011 \quad$ Published: March 1, 2012

doi:10.5539/enrr.v2n1p47

URL: http://dx.doi.org/10.5539/enrr.v2n1p47

\begin{abstract}
Goulbi Maradi valley is a temporary flow stream with a basin containing great agro-ecologic potentials. However, this potential is dwindling at a rate that corresponds with increase in the ecosystem's vulnerability. This study is focused on a part of this basin, an area of about $2600 \mathrm{~km}^{2}$. The aim of this study is to better understand land use/cover change through diachronic analysis by integrating remote sensing and GIS. Visual interpretation of satellites imagery (1972, 1986, and 2001), field works, technical and survey data were used to provide quantitative analysis of Land Use/Cover change information and its greatest drivers in the study area. The changes become more and more important under simultaneous influence of successive droughts (1973-1974 and 1983-1984) that have disrupted ecological balance, anthropogenic and animal impacts, ecosystems degradation and politico-institutional policies. In fact, the land use temporal dynamics are characterised by the continual degradation of vegetation, the complete state of land saturation (resulting in conflicts between farmer and herders), the narrowing of grazing areas, bare land expansion, the bank erosion of stream bed, the decline in flooded plain and precariousness of flooding surface of the study area.
\end{abstract}

Keywords: Land saturation, Ecosystem degradation, Goulbi Maradi Valley, Temporal dynamics

\section{Introduction}

In the early twentieth century, the world forest area was estimated at 5 billion hectares. This figure has reduced to 2.9 billion hectares. This represents almost a double of the world's cultivated area. These declined forests are mainly concentrated in developing countries where implementation of policies to reduce emissions from deforestation encounters big challenges, and where capacity for deforestation monitoring is well-advanced in a few countries and is a feasible goal in most others (Ruth D. et al., 2007). From 1990-1995, the loss of forests in these countries has averaged 13 million hectares per year or 6.5\% per decade (Lester R. Brown, 2009). Clearing for agriculture to ensure food sufficiency for the growing populations is partly responsible for the forests destruction (Ziyong S. et al., 2008). In the last few decades, conversion of grassland and forest into cropland and 
residential areas has risen radically due to population growth, food scarcity, and urban sprawl (Houghton R. A., 1994; Meyer W.B. \& Turner B.L., 1994). Recent climate change studies throughout the world have shown that the effects of land use/cover changes have modified the background level of carbon storage in the vegetation and soil (IPCC, 1995; Upadhyay, T.P., Sankhayan, P.L., Solberg, B., 2005; Lal, R., 2004; Palumbo et al., 2004; Follett et al., 2005; Jones, M. B. \& A. Donnelly, 2004).

The conversion from forest land to land crops, such response adopted by farmers in the semi-arid areas (Casenave A. \& Valentin C., 1989) is an increasingly important dimension in the Sahel and this is a major concern, causing land degradation. Recurrent droughts in Niger, the increased degradation of natural resources in addition to the increase in human population and livestock density positions the country in the "environmental change" context of Sahelian countries. Land use changes and their ecological effects constitute one of the hotspots of global change research and reflect the relationship between human being and nature, with integrative and regional feature. In fact, all agro-ecological zones in Niger undergo changes quickly perceptible, in response to the cumulative effect of anthropogenic and natural factors hindering heavily the ecosystems regenerative capacity of different watersheds of the country, such as the Goulbi 'Maradi valley, the object of this study.

To improve understanding of land changes under diverse cultural, economic, political, institutional, and environmental situations, some investigators have carried out a flurry of studies about the causes and consequences of land use change spawned recently (Meyer W.B. \& Turner B.L., 1994; Lambin E.F. et al., 1999) both at world and regional levels. Many studies based on ground measurements and/or interpretation of remotely sensed data have been carried out to monitor the spatial and temporal variability of landscape (Karnieli A. et al., 2008) and environment through land use and land cover changes assessment. Many biotic, abiotic, and environmental effects caused by land use/cover changes have attracted much attention of some researchers throughout the world (Brooks et al., 2006; James et al., 1999; Ludwig et al., 2001; Perkins \& Thomas, 1993). However, at local level most literature on land use/cover shifts considered a small portion of space (Aboubacar I. et al., 2007) or analyzed and emphasized on particular phenomenon such as deforestation among others. This study, on the other hand, focuses on all of the land use/cover units within the study area. The particularity of this study is also reflected in its provision of detailed information about some land use units dynamics (grazing area and livestock or transhumance corridor) which have not attracted much attention in previous studies which has left the problem inadequately addressed.

This study aims not only to detect the long term land use/cover shifts (from 1972 to 2001) in Waro-Souloulou area, but also to determine the greatest drivers of the shift. The Waro-Souloulou area is included in Goulbi Maradi basin where remote sensing and geographical information system (GIS) was applied in order to provide quantitative analysis of land Use/Cover Change information in this area. This study will be of immense importance in this area where many NGOs are involved in developmental projects. Land use/cover shifts study creates a novel statistics that helps to describe the interactions between human activities and their environment.

\section{Study Area Background}

The Goulbi Maradi originated from the granite mountains of Kano, Nigeria and crosses through the Maradi area of Niger where it describes a loop about $150 \mathrm{~km}$ long, and then returns to Nigeria to join the Rima River which is a left bank tributary of the Niger River. Its drainage basin covers an area of $9787 \mathrm{~km}^{2}$, of which $3803 \mathrm{~km}^{2}$ is located in Nigeria and the remaining $5984 \mathrm{~km}^{2}$ in Niger. The entire basin is located between 1300 ' $1330^{\prime} \mathrm{N}$ latitude and $6^{\circ} 00^{\prime}-9^{\circ} 00^{\prime} \mathrm{E}$ longitude (GIOES, 2007). The study area is a portion of the Goulbi Maradi watershed in the Niger part and it covers $2600 \mathrm{~km}^{2}$ (43.4\% of the Niger part of the basin area) and is located between 13 $50 ' 55$ "and 13 14'47"N latitude and 6 23'54" and 07'41"7 E longitude (fig.1).

The climate type is Sahelian, characterized by two types of seasons. There is a rainy season lasting three to four months (June to September) and a dry season that describes the remainder of the year. Rainfall is concentrated in three months and dispersed unevenly around the area. In addition, the quality of the rainy season varies greatly from year to year. Mean annual rainfall varies from $450 \mathrm{~mm}$ to $500 \mathrm{~mm}$ and the rainfall gradient decreases from south to north. The area is marked by recurrent droughts (1973-1974 and 1983-1984). The watershed of Goulbi Maradi valley is located at the eastern edge of Iulliminden sedimentary basin. The Geomorphology is characterized by Plateaus associated with sandy plains in this area (Dan D. A. et Moussa I. B., 2000). The predominance of the textured sand-silt soil in the area confers it an effective agricultural development area. On the other hand, the lateritic plateaus are assigned to pastoralism, the hydromorphic soil of hollow is the privileged environment for irrigated crops.

In fact, the potential (land, water, wildlife and vegetation) contained in this basin is a unique environmental asset in the changing Sahelian Zone where the eco-environmental change is very sensitive driven by climate change 
and human activities. But it is clear that for several decades, the unprecedented and still ongoing environmental and socio-economic changes in this area have undermined considerably the potential of its ecosystems.

This watershed constituted a particular ecosystem where the degradation is on a major scale and much more pronounced considering the multiple activities performed on the different geomorphological units of this area. Ecosystem degradation of the watershed is a major problem and has gotten worse in recent decades, becoming a major concern. The loss of biodiversity resulting in the loss of ligneous resources every day, affecting the ecological balance of the environment (Yamba B., 1995), land degradation due to wind and water erosion, changes in surface features resulting in the extension of barren land, disruption of the hydrological regime and downward trend of water table, and the deepening of the Goulbi stream bed, all these are forms of damages observed in the Goulbi Maradi watershed.

The study area is characterized by a high population density within the country leading to an intense pressure on natural resources. Amongst the easily notable changes by most local people were the significant reduction of plant cover, the depletion of water resources due to drying and the silting up of rivers, and land degradation as well as its productivity. This situation has lead to a drop in crop yields as well as poor harvest thereby exposing the local population to food crises and famines. The coexistence between farmers and stock breeder in the area often lead to conflicts relating to the use of space and natural resources. Sometimes, grazing areas and corridors are nibbled therefore sparking off permanent conflicts between farmers and herdsmen. An example is the Toda tragedy of 1992 which resulted in the deaths of 104 persons in the study area.

\section{Materials and Methods}

In total, multidate datasets were used as fundamental data in this study. Landsat1 MSS acquired on 7 November 1972, Landsat5 TM acquired on November 28 1986, and Landsat ETM+ acquired on November 292001 (chosen because it was the last imagery available) (Table 1), and a panchromatic image for re-sampling, all constituted the source of data. These images were in individual bands (Table 1) in GEOTIF format of USGS. These bands were imported and combined into a single multispectral image. Then, Landsat TM false colour composite satellite imagery (reference year 1972) was carried out. During this operation, three fundamental colours have been attributed to the three image bands. The results were: near infrared band was coded red colour, red band was coded green colour and green band was coded blue colour. Indeed, on-screen observation of colour composite showed the presence of vegetation in deep red, crops in light read, lateritic plateau in blue, water in light blue, bare land in green, the flood plain in black and so on. Thereafter, Mosaic images were operated. In total two scenes (Guidan Roumji's scene and Maradi's scene) that concern the study area, have been used for imagery mosaic. During the process in which ArcView GIS 3.2 was used, the scenes were geo-referenced using UTM geographic projection system. When each scene was fully digitized and transformed into the adopted reference system, the individual scenes fused to a single image. The ETM+ image was geo-referenced using ground control points, and then the MSS and TM images were geo-referenced using the pre-defined ETM+ as reference coordinates. Igbokwe J. I. (2010) noted that higher resolution image can be re-sampled to a lower resolution image and vice versa. After extracting the concerned study area, all images were re-sampled to a lower resolution $(14.25 \mathrm{~m})$ in order to improve and optimize treatment output, make clear all land use/cover units in the study area and identify them perfectly.

Visual interpretation of images was adopted as methodology because of the availability of a sound knowledge about the study area. Target recognition was the key to the interpretation and information extraction. The observation of differences between targets and their backgrounds involves comparing different targets based on a combination of the following characteristics: tone, shape, size, pattern, texture, shade and association.

Digitizing contours of thematic entities, descriptive attributes capture were carried out. Indeed, based on field trip checking information the pixel matrices contours for each type of land use/cover were identified and delineated on-screen; in total 1200 polygons were digitized. All data extracted were hosted in layers created (hydrographical network, roads network, and different land use/cover units). After digitizing and filing layers, the attributes capture was made. Then, objects layer of land use/cover have been defined by creating a table containing the different units of land use/cover and digital key code for linking each polygon, line and point to all of its attributes. All polygons are well described and their areas and perimeters were documented. Individual land use/cover maps were created using the same process as above. After carrying out all maps in GIS and Remote Sensing laboratory, a second field mission was conducted to check and correct errors. It should be mentioned that a first field mission was undertaken after carrying out the false colour composite with a view to identify the land use/cover units which were thirteen according to the Niger land use/cover nomenclature and this fact was established. Then, in order to quantify land use/cover detection change, maps overlay were 
produced from Visual interpretation imageries (Landsat1 MSS and Landsat ETM+; Landsat1 MSS and Landsat5 TM; and Landsat5 TM and Landsat ETM+).

With regard to the sampling process of survey for determining land use/cover change drivers, three sites (Waro, Souloulou, and Toda), each comprising of some villages were explored. In each of these sites, a representative sample of $15 \%$ of each village was calculated. Then, in each village a representative sample of $15 \%$ of households was determined. During the investigation, first priority was given to individuals constituting the sample, then, informal interviews were undertaken with a view to seeking additional information to confirm whether or not the data collected during the first interviews were reliable. The questionnaire was mainly emphasized on direct and indirect land use/cover drivers arranged as follows: (i) Influence of fluctuations in climate factors such as rainfall irregularity, poor rainfall distribution in time and space, and recurring drought cycle; (ii) Influence of demographic pressure such as high population growth rate; (iii) Influence of bad practices in the use of natural resource; (iv) Influence of cultural factors; and (v) Influence of political-institutional factors. Other sources of data include; climate data, demographic data etc. SPSS software was used for analysing the sample survey results.

\section{Results}

\subsection{Land use/cover change}

According to Niger land use/cover nomenclature and the one from Aboubacar et al. (2007), thirteen land use/cover units were identified. These are: continuous pluvial culture / fallow; grazing Area; crops under wooded park; shrub savannah; raised savannah; flooded area; Transhumance corridor; crusted surface; Aquatic prairie; Bare plateau; Channels flow; Ponds/basins; and stream bed (Table 2).

As can be observed from summary Tables 2 and 3, the Land use/cover change of Waro-Souloulou area since 1972 was significant. Between 1972 and 1986, the grazing area decreased from $9.61 \%$ to $7.70 \%$ and by 2001 , it had fallen to $7.52 \%$ due to cultivated area increase (Table 3). Within the same year under review (1972 to 1986 down to 2001), while on one hand the complex of continuous pluvial culture/fallow area increased from $68.83 \%$ to $71.41 \%$ and finally decreased gently to $71.32 \%$, crop under wooded park area decreased continuously on the other (Table 3). With regard to bare land, it increased continuously from $1.19 \%$ to $2.14 \%$ and $3.37 \%$ for crusted surface, and $1.05 \%$ to $1.55 \%$ and finally $1.73 \%$ (respectively for the year under review) for the bare plateau. This trend can be attributed not only to land cultivation in order to increase food production, but also because of overgrazing (Fig. 3, 4 and 5). With a $0.32 \%$ value in 1972, the area of basins and ponds became $0.39 \%$ in 1986 before reaching $0.38 \%$ in 2001. Following the erosion of its banks, stream bed of Goulbi deepened and widened at the same time resulting in a cumulative $0.83 \%$ increase (1972 to 1986) (Table 3). But between 1986 and 2001, the area of Goulbi bed stream was fixed due to the construction of erosion control structures along its banks. Before the seventies, natural vegetation cover in this area was very good. Since the beginning of chronic droughts periods, rapid urbanization and other socio-economic activities, (decades 70 and 80) natural vegetation saw a decrease. In fact, the decrease in shrub savannah and raised savannah were similar between 1972 and 1986. This downward trend persisted for the raised savannah while the shrub savannah showed a $1.41 \%$ increase due to a new vegetation (Table 3) protection policy undertaken by government from 1986 to 2001. In 1972 Channels flow occupied $0.97 \%, 0.92 \%$ in 1986 and $0.57 \%$ in 2001 as a result of siltation. Flooded area decreased between 1972 and 1986 but increased between 1986 and 2001 (Table 3). This improvement was achieved, thanks to the civil engineering structure constructed within the framework of Goulbi Maradi valley development project for storing floodwater in full spate.

\subsection{Drivers of land use/cover change}

The driving forces are mainly biophysical and socioeconomic factors which lead to the change of land use patterns and goals. In a natural ecosystem, the principal driving forces include; climate, soil and hydrology whereas, the socioeconomic driving forces are usually grouped into some types including: population and livestock fluctuation, livelihood, cultural practices, development in rural economy, political and economic pattern.

Climate fluctuations are manifested by successive droughts (1973-1974 and 1983-1984) that affected the area, leading to lower rainfall characterised by irregularity in time and space. Indeed, the cumulative effects of drought and irregular pattern of rainfall have lead to a rapid degradation of the ecosystem and vegetation cover and of course low crop yield. This trend exacerbated the clearing of land for agricultural development. Chronic drought has decimated much of the stock thereby contributing to the settling of the hitherto herders, prompting the emergence of new needs for cropland. Indeed, the dry years engendered the change in flow regime of Goulbi, which consequently exacerbates the trend towards a reduction not only in duration of flow, but also the surface 
of the aquatic prairie. Flooded area decreased between 1972 and 1986 (Table 3).

Wind erosion in the area has a very key influence on its land use/ cover change. There are two types of winds; the monsoon and harmattan. The wind action is very effective, with a speed that varies from $4.1 \mathrm{~m} / \mathrm{s}$ to $2.5 \mathrm{~m} / \mathrm{s}$. An effective wind is able to move mineral particles with a diameter of $160 \mu \mathrm{m}$ or greater $(\geq 160 \mu \mathrm{m})$ with a speed greater than or equal to 3m/s (Bagnold 1954 cited by Karimoune S., et al., 1990). Granulometric analysis showed that the principal mode was $0.160 \mathrm{~mm}$ (A. Bagni, 2009) meaning the land surface is composed of fine-grained, leading to mobilization of soil material by wind. The wind erosion is equally significant as contributor to the acceleration of siltation in basins and ponds consequently reducing their areas. The same situation also contributed to the loss of the thin topsoil that covered the surface of the cuirassed plateau which was a result of overgrazing, thus promoting its spread.

Rapid population growth in this area had played a vital role on its land use pattern. With a very high average annual growth rate of $3.1 \%$ for the period $1988-2001$ and an average density of $7.2 \mathrm{hbts} / \mathrm{km}^{2}$, the population of the area exerts an ever-increasing pressure on the ecosystems. In addition, the increase in population results in the emergence of new needs, part of which is food production. This situation further accentuated the pressure on land resources with a consequent reduction in fallow periods (from 10 to 2 years) or even the complete absence of fallow. Because Population growth is directly proportional to demand for agricultural products, there was a consequent need for farmland.

A direct consequence of population pressure is the extension of cropland at the expense of grazing areas and savannahs (Fig. 2), causing significant deforestation and expansion of bare land. Changes in age population structure (more youths than ever) and migration from north to south also had its influence on the land use/cover change. More able-bodies simply mean more agricultural workers and in turn, increased land use needs. An average household in Maradi is consisted of 8 persons out of whom 3 are agricultural workers, according to Amoukou A. I. (2006). The dynamics of the population was marked by the migration and concentration of populations to the south, as an aftermath of drought. "Formerly we needed to even hire labour but now we have abundant and available farm workers for our entire field. As we speak, if we should find a field to clear, there is enough hands available", said a farmer from Souloulou village, during an interview concerning land use/cover change.

Practiced mainly for subsistence, agriculture is characterized by low productivity. The low productivity is a direct consequence of the precarious rainfall, inappropriate farming techniques (which also does not match the present situation of local population growth), and the constant soil fertility impoverishment. The population is thus exposed to food insecurity. The farm area has encroached into other sections like grazing area, protected areas (forests, protected areas, savannas) and even on marginal lands. More especially, the cultivation of marginal lands exacerbated land degradation in the watershed and also amplified the soil erosion phenomenon. As agriculture mechanization becomes more and more important, the use of ploughs for agricultural purposes has increased. This situation allows farmers to cultivate more fields. Agricultural production methods influence on the environment in variable forms (Casenave A. et Valentin C., 1989). Tillage is well dominated by the practices of animal-drawn ridging which also shapes keenly surface features in favour of run-off, if it is done perpendicular to contour lines, resulting in soil erosion. Worthy of mentioning also, is the monetization of the rural economy in the area informed by the production of export crops such as groundnuts. The Groundnut boom which occurred in southern Niger in the 1930s especially in Waro-souloulou area had led to the emergence of new needs for cropland resulting not only in massive land clearing, but also depletion of its productive capacity.

It was recorded that the livestock population in Guidan Roumdji department increased significantly in terms of numbers. It went from 301,986 head of cattle in 1972 to 223,442 head of cattle in 1986 and reached 408,030 head of cattle in 2001. This growth has had serious consequences on the environment. The activities related to livestock play an important role in the process of the soil denudation from trampling, soil compaction and overgrazing. The trampling on soil doubly impacts on land degradation process; soil denudation and soil structure destruction. Because herders subscribe to a particular route, making it a daily business of Trampling, the situation gets even worse. Following the repeated passage of animals, a combination of pathways as a result and slope effects constitute a privileged drainage channels on the occasion of heavy rains, resulting in significant linear soil erosion at the first stage and gradually gullies. Trampling has caused a compaction of the top soil, reducing its porosity thus generating the formation of crust erosion and crusted surface extension. The droughts of 1973-1974 and 1983-1984 resulted in extensive farming development causing reduction of pasture areas. This situation provoked a significant increase in cattle pressure on natural vegetation areas which was already weakened by drought (shrub savannah and raised savannah) causing its destruction. 
In order to ensure their livelihood, people practice some activities such as craft. Indeed, as an income generating activity for women (van weaving, mats) and other social classes (blacksmiths, sculptors), the craft has greatly influenced the land use dynamics. In fact, the uncontrolled, abusive and irrational exploitation of tuffs palm doum (Hyphaene thebaica), for making mats, vans, string and other marketing products, exposed the soil to the aggressive action of raindrops which in turn lead to the breaking of soil aggregates and thus promoted the formation of crust, which increased the surface of bare land. In addition, the excessive use of Prosopis Africana, an endangered species, preferred (by blacksmith) for its perfect calorific value and mortar sculptors due to its hardness, density and durability. This species, according to $54.26 \%$ of farmers questioned is becoming extinct. Its extinction could make a transposition to other species with high calorific value and affect in consequence the entire ecosystem.

The way a community manages her space and resources is strongly influenced by cultural values and this is can also affect the land use dynamics. The competition between farmers to acquire the coveted honorary title of "Sarkin Noma" (farmer who records the highest agricultural production rate in the area) has led many farmers to cultivate more and hence massive land clearing for agricultural use. The Islamic theory that encourages procreation in order to expand the Muslim community has also aided population growth which provoked a negative trend in land use/cover patterns. Fallow was also negated as a result of inheritance which rendered some hitherto, family farmlands to individually owned ones.

Land use/cover changes were also influenced by the effects of certain decisions made by political institutions, government and even traditional authority. Indeed, at the national level, a number of policies have been adopted and implemented in order to ensure environmental protection and the sustainable management of natural resources but the policies failed to address the needs of the local population. Through the lack of participative management of natural resources, forests that have been declared "classified domain" by decree No.2386/SE/F of April 81956 and No.5895/SE/F of October 271951 respectively, the forests of Kouroungoussaou and Guidan Roumdji have been affected by deforestation and agricultural land encroachment.

Since the construction of the Jibiya dam in Nigeria in 1989, the Goulbi Maradi has experienced an unsteady rate of flow resulting in the decline of flooded area. With a height of $23.5 \mathrm{~m}$ and a total length of 3,660 m, this dam has a capacity of 142 million $\mathrm{m}^{3}$ and was built to support irrigation and water supply.

\section{Discussion}

Within the framework of land saturation and declining soil fertility, government's intervention in the rural sector decreased significantly which have resulted in serious consequences on land use/cover dynamics. During the 1970s, government policies begat a heavy debt on the country and remained unpaid even after the uranium boom. Economic difficulties led the government to register in 1984 in structural adjustment Programs imposed by backer (World Bank and IMF) aiming to cut down on the government spending in fields where the private sector efficiency was considered superior. There were two main effects of this reform program including a drastic reduction of government investment in rural development (Hamadou S., 2000, cited by Yamba B., et al., 2001), and the cereal markets liberalization including the end of public monopoly service in charge of the purchase. Niger's government privatized and liquidated as well (or reduced activity) several public enterprises in charge previously of input supply and marketing (Hamadou S., 2000). In the study area, Rural Development Project of Maradi (PDRM) which aimed to provide in substantial cost, a great amount of subsidized fertilizer, equipment pulled by animals as well as credit systems were liquidated. The pitch has consequently made farming more extensive in order to maintain production yield levels.

As in the entire Sahel region, the overall decline in rainfall, severe poverty especially in rural areas, and scarcity of arable land are among other major challenges facing the people of the study area. This situation created a total transformation in cultivation and agro-pastoral practices. Before 1975, the long fallow use was widespread throughout the Region of Maradi and manure spreading by hand to fertilize the fields was not performed (Yamba B. et al., 2001). Nowadays fallow has more or less been abandoned. The fallow abandonment was without any mitigation measures in order to increase soil fertility. Despite the fact that the Rural Development Project Maradi (PDRM/1977 to 1984) was ongoing, the percentage of cultivated fields receiving organic manure or mineral fertilizers decreased from 1977 to 1984. This project which was operational from 1978 to 1986 allowed the distribution of subsidized mineral fertilizer. Since 1988, fertilizer use has recorded a staggering fall (Moussa I. B., 2000).

The rapid population growth and migration has resulted in land saturation (land saturation is defined as the depletion of arable land available that are allocated by the chief members of the community). The creation of Hausa kingdom in Maradi had attracted migrants from the south (Yamba et al., 2001). Then, during the French 
colonialism, the movement of the pioneer communities towards the northern areas in search for lands grew and as such, the virgin areas became gradually occupied (Raynaut et al., 1988 cited by Yamba B. et al., 2001). During the first phase of settlement of the Maradi community, because population density was low, migrated communities practiced itinerant agricultural systems or long fallows (10 years or more) which was enough to allow forest/vegetation regeneration and restoration of soil nutrients through the decomposition and degradation of organic matter (Mousa I. B., 2000). Land saturation and high rural population densities indicate that the Natural resource Management is not possible through fallow. This reflects either a breakdown or the radical change in agricultural systems.

Meanwhile, owing to the growth of village populations and their progressive involvement towards the marketing of groundnuts, the pressure on arable land availability was increased. Farmland areas encroached into natural forests and grazing land (Table 3 ) and continued to increase accentuated by way of consequence the decline in agricultural yield. Indeed, owing to the deforestation and grazing areas reduction throughout Maradi Region, the food needs of cattle, all year round, could not be met. Transhumance (towards south and Nigeria) lowers the amount of animal manure available because the usual feed for manure contracts cannot be established. This phenomenon results in a decrease in soil fertility. Increased use of crop residues not only for fodder deficits but also as fuel by rural households had lowered soil fertility consequently its productivity.

The breakdown of farm units had its own consequences on land use dynamics particularly as it increases pressure on land and reduces fallow. The growing influence of government has reduced significantly the powers of the local heads in terms of land tenure systems. As a result, the powers exercised concerning land tenureship by lineages through the head of the family (maigida) increased and there was land individualisation and control exercised even by smaller family units or individuals belonging to lineages (Yamba B., 2000). This trend was observed for the first time, 30 years ago (Gregoire E., 1980, Raynaut et al., 1988). In fact, land use system based on the extended family (gandu) no longer exists in some areas, particularly in the south where the pressure on land is higher. Other factors (e.g. high taxes, Islamic law) have accelerated the trend towards the individualization of land rights and control. The less common use of fallow, and ultimately its disappearance, affected the cultivated lands fertility. In addition, the contribution to land fertility from animal manure was not sufficient to offset the reduction in fallow periods.

In some regions of Niger, the same way as in study area, agricultural expansion has increased through mechanisation of tillage. Indeed during economic boom of groundnut and until 1975, the cultivated land has grown rapidly because of the deployment of ploughs able to cultivate compacted soils that have been long neglected by farmers in favour of dune sandy soil which was easy to work. The use of Ploughs was a major factor in soil structure degradation leading to encrusted surfaces extension.

Grazing areas drop and pasture quality deterioration lead to lower animal load capacity in the area. Such reduction could be exacerbated by scarce rainfall effects especially on biomass production in the grazing areas. Drought cycles of the 1970's and 1980 have resulted to a decrease in stages of animal load capacity model (Peyre de Fabrègues, F., 2000). This has increased from approximately 4.5 million tropical livestock units in 1964-1972 to 2.75 millions in 1973. This figure rose to 4.6 million in 1983 but fell even lower in 1986 reaching 2.1 million before recovering to reach 3.2 million in 1999 (A tropical livestock unit (TLU) is equivalent to a camel, 1.25 of cattle (or $250 \mathrm{~kg}$ ), or ten sheep / goats).

When grazing areas become rare, herders usually lead their flocks to other locations in the south or even to Nigeria for a part of or the entire year. This reduces the amount of animal manure available for the establishment of pasture/manure contracts between farmer and herdsman. Despite the clarifications contained in the tenure and access rights to natural resources in the Rural Code of 1993, grazing areas and livestock corridors continue to decline leading to permanent conflicts between farmers and herdsmen in Niger. The 1993 code explicitly addresses pastoral land use including pastoral "farm house" definition, and the identification and demarcation of livestock corridors.

As in the entire Sahelian zone, the study area is characterized by reduced natural vegetation cover. In addition to clearing for cultivation, destruction of forest resources is also caused by water deficits, and the actions of herdsmen who now lead their flocks southwards of the pastoral zone in order to find enough forage and pruning is practiced in the process (Moussa, I. B., 2000).

In Niger there is a perpetual conflict between the land tenure legislation, which tends to encourage business development and the forest legislation, which had a more sceptical attitude towards the development of this sector (Elbow \& Rochegude, 1989 cited by Yamba B. et al., 2001). The principle of "development", which allowed people farming unoccupied land to appropriate them, contradicted the forestry legislation of 1974, and 
this is a regular conflict (Yamba B. et al., 2001). The forest legislation placed the government in charge of all forest lands that "were not in use" and allows the strict protection of some tree species. These conflicts had some disadvantages like the discouragement of farmers to participate in the protection and planting of trees in forest areas, or even within their farmland. Moreover, during the 1970s, many farmers also feared that government's efforts at encouraging them to plant trees on their lands were a maneuver in order to acquire their control (Yamba B., 2000).

\section{Conclusion}

Land use/cover change in the study area has been effectively demonstrated by using satellite imagery. A set of tools was specifically used to generate land-use/cover information from interpretation of satellite imageries in the case of Waro-Souloulou area. This has shown the value of remote sensing tools and the importance of GIS in analyzing land use dynamics as it has affected the Waro-Souloulou environment. Thus, the results were corroborated by qualitative observations of the land in order to generate land dynamic situation map. Thus, the analysis based the three periods $(1972,1986$, and 2001) suggested that already by the year 1972, agricultural land had began to show signs of saturation. This is evident from the fact that during this period, more than $68 \%$ of the total land of the study area has been cultivated. The analysis reveals a decrease in cropland area. This reflects a saturation property and a high rate of land use. The dynamics is also marked by the growing decline in grazing areas and corridors in favour of the crop areas. Also, the areas of lateritic plateaus and encrusted surfaces increased during the period under review. More so, due to increasing population, fallow is becoming a thing of the past. The observed decreases in forest cover have two significant potential implications: decreased carbon sequestration that has consequence on climate change and decreased forest habitat for wildlife species

Land use change, the role of human activities and institutions in bringing the change, and the consequences of the change require careful consideration by land managers and policy makers in order to preserve environmental resources (Naiman et al., 1997).

\section{Acknowledgements}

We wish to express our thanks to Pr. Yamba Boubacar who provided a great deal of professional help. We would like to thank Dan Karami Ado for providing technical assistance and Souley Aboubacar, "National coordinator of Integrated Ecosystems Management in the Trans-boundary Areas between Nigeria and Niger" project. We express also our thanks to Dan Lami Musa Saluhu.

\section{References}

Aboubacar, I., et al. (2007). L'analyse diachronique de l'occupation des terres et caractéristiques de la végétation dans la commune de Gabi dans la région de Maradi (Niger). In sécheresse, n¹-2, vol 17, Edition John Libbey Eurotext Montrouge- France.

Amoukou, A. I. (2006). Impacts des investissements dans la gestion des ressources naturelles sur les systèmes de production dans les Régions de Maradi, Tahoua et Tillabery au Niger. 31 pages.

Bagni, A. A. (2009). Etude géomorphologique et évolution du couvert végétal dans les aires verdies et non verdies du Sahel: cas des terroirs de Warzou et de Maissakoni dans la commune rurale de Sherkin Haoussa (Département de Mayahi-Région de Maradi), 84 pages.

Brooks, M.L., Matchett, J.R., \& Berry, K.H. (2006). Effects of livestock watering sites on alien and native plants in the Mojave Desert, USA. Journal of Arid Environments, 67, 125-147. http://dx.doi.org/10.1016/j.jaridenv.2006.09.022

Casenave A. et Valentin C. (1989). Les états de surface de la zone sahélienne. Influence sur l'infiltration; Edition ORSTOM, collection Actiques, 229 pages.

Dan D. A. et Moussa I. B., et. (2000). Action de seuils en gabion sur la protection des berges et l'épandage des crues du Goulbin Maradi. In Annales de l'Université Abdou Moumouni de Niamey.

Diress et al. (2010). Land-use/cover dynamics in Northern Afar rangelands, Ethiopia Agriculture, Ecosystems and Environment, 139, 174-180. http://dx.doi.org/10.1016/j.agee.2010.07.017

Follett, R.F., Castellanos, J.Z., \& Buenger, E.D. (2005). Carbon dynamics and sequestration in an irrigated Vertisol in Central Mexico. Soil Till. Res., 83, 148-158. http://dx.doi.org/10.1016/j.still.2005.02.013

GIOES. (2007). Rapport final Etude sur l'identification et la caractérisation des sites pilotes du projet gestion intégrée des écosystèmes transfrontaliers Niger Nigeria.

Grégoire, E. (1980). Etude socio-économique du village de Gourjae. Délégation Générale à la Recherche 
Scientifique et Technologique (DGRST), Paris.

Grégoire, E., \& Raynaut, C. (1980). Présentation générale du Département du Maradi, DGRST, Université de Bordeaux II.

Houghton, R. A. (1994). The worldwide extent of land-use changes. Bioscience, 44, 305-313.

Igbokwe, J. I. (2011). Analysis of Landuse and Landcover Changes of Aba Urban Using Medium Resolution Satellite Imageries (online).

IPCC, Intergovernmental Panel on Climate Change. (1995). IPCC Second Assessment- Climate Change: A Report of the Intergovernmental Panel on Climate Change. Cambridge University Press, Cambridge.

James, C.D., Landsberg, J., \& Morton, S.R. (1999). Provision of watering points in the Australian arid zone: a review of effects on biota. Journal of Arid Environments, 41, 87-121. (Available online at: http://rrwww.idealibrary.com)

Jones, M. B., \& A. Donnelly. (2004). Carbon sequestration in temperate grassland ecosystems and the influence of management, climate and elevated CO2. New Phytologist, 164, 423-439. http://dx.doi.org/10.1111/j.1469-8137.2004.01201.x

Karnieli, A. (2008). Assessing land-cover change and degradation in the Central Asian deserts using satellite deserts using satellite image processing and geostatistical methods, Journal of Arid Environments, 72, 2093-2105. http://dx.doi.org/ 10.1016/j.jaridenv.2008.07.009

Karimoune, S., et al. (1990). Désertification dans le sud nigérien: interprétation d'une image SPOT. In Outils micro-informatiques et télédétection de l'évolution des milieux, Actes du colloque de Toulouse. AUPELF. Presse de l'université du Québec. Canada, pp77-106.

Lal, R. (2004). Soil carbon sequestration to mitigate climate change. Geoderma, 123(1-2), 1-22. http://dx.doi.org/10.1016/j.geoderma.2004.01.032

Lambin, E.F., et al. (1999). Land-use and land-cover change (LUCC) implementation strategy. IGBP Report No. 48 and HDP Report No. 10. IGBP, Stockholm.

Lester, R. B. (2009). Eco-Economie, une autre croissance est possible, écologique et durable.Edition du seuil, Chapter 3.

Ludwig, J.A., Coughenour, M.B., Liedloff, A.C., \& Dyer, R. (2001). Modelling the resilience of Australian savanna systems to grazing impacts. Environment International, 27, 167-172.

Marc C. et Bernard T. (1995). Utilisation des terres de parcours par l'élevage et interactions avec l'environnement, CIRAD-EMVT, 95 pages.

Meyer, W. B., \& Turner B.L. (1994). Change in land use and land cover: a global perspective. Cambridge University Press, Cambridge.

Moussa, I.B. (2000). Gestion des ressources naturelles et évolution des systèmes agraires dans la région de Maradi, Drylands Research Working Paper 28. Drylands Research, Crewkerne, Royaume-Uni.

Naiman RJ, Bisson PA, \& Turner MG. (1997). Approaches to management at the watershed scale. In: Kohm KA, $\&$ Franklin JF. (eds). Creating a forestry for the 21st century: the science of ecosystem management. Island Press, Washington, DC, 239-253.

Palumbo, A.V., McCarthy, J.F., Amonette, J.E., Fisher, L.S., Wullschleger, S.D., \& Daniels, W.L. (2004). Prospects for enhancing carbon sequestration and reclamation of degraded lands with fossil-fuel combustion by products. Adv. Environ. Res., 8, 425-438. http://dx.doi.org/10.1016/S1093-0191(02)00124-7

Perkins, J.S., \& Thomas, D.S.G. (1993). Spreading deserts or spatially confined environmental impacts: land degradation and cattle ranching in the Kalahari Desert of Botswana. Land Degradation and Rehabilitation, 4, 179-194.

Peyre de Fabrègues, F. (2000) Les grandes étapes de l'élevage en zone pastorale au Niger et leurs conséquences majeures, Atelier régional, Les approches de la gestion des pâturages et les projets de développement: quelles perspectives?, 2-6 October, 2000, Niamey.

Ruth D., et al. (2007). Earth observations for estimating greenhouse gas emissions from deforestation in developing countries. Environmental Science \& Policy, $10, \quad 385-394$. http://dx.doi.org/10.1016/j.envsci.2007.01.010 
Sun, Ziyong, et al. (2008) Using Landsat data to determine land use changes in Datong basin, China. Environ Geol., 57, 1825-1837. http://dx.doi.org/ 10.1007/s00254-008-1470-2

Upadhyay, T.P., Sankhayan, P.L., \& Solberg, B. (2005). A review of carbon sequestration dynamics in the Himalayan region as a function of land-use change and forest/ soil degradation with special reference to Nepal. Agric. Ecosystems Environ., 105, 449-465. http://dx.doi.org/10.1016/j.agee.2004.09.007

Yamba, B. (1995). Essai d'interprétation de l'échec des problèmes environnementaux au Niger, revue de géographie Alpine, Université Scientifique et médicale de Grenoble: 65-81 pages.

Yamba, B. (2000). Evolution des régimes de propriété et d'utilisation des ressources naturelles dans la région de Maradi, Drylands Research Working Paper 29. Drylands Research, Crewkerne, Royaume-Uni.

Yamba, B., et al. (2001). Synthèse sur les évolutions a long terme dans le département de Maradi, Niger 1960-2000, Drylands Research Working Paper 39f, 70 pages.

Table 1. Characteristics of images required

\begin{tabular}{|c|c|c|c|c|c|}
\hline Satellites & sensors & reference & Date & resolution & Bands \\
\hline \multirow{2}{*}{ Landsat7 } & \multirow{2}{*}{ ETM+ } & P190ro50 & \multirow{2}{*}{$29 / 11 / 2001$} & \multirow{2}{*}{$28,5 \mathrm{~m}$} & \multirow{2}{*}{$2,3,4$} \\
\hline & & P190r051 & & & \\
\hline \multirow{2}{*}{ Landsat5 } & \multirow{2}{*}{$\mathrm{TM}$} & P190r050 & \multirow{2}{*}{ 28/11/1986 } & \multirow{2}{*}{$28,5 \mathrm{~m}$} & \multirow{2}{*}{$2,3,4$} \\
\hline & & P190r051 & & & \\
\hline \multirow{2}{*}{ Landsat1 } & \multirow{2}{*}{ MSS } & $\mathrm{P} 204 \mathrm{r} 050$ & \multirow{2}{*}{$7 / 11 / 1972$} & \multirow{2}{*}{$57 \mathrm{~m}$} & \multirow{2}{*}{$2,3,4$} \\
\hline & & P204r051 & & & \\
\hline
\end{tabular}

ETM $+=$ Enhanced Thematic Mapper plus; MSS = Multi Spectral Scanner; TM= Thematic Mapper

Table 2. Land use/cover states in 1972, 1986 and 2001 in Waro-Souloulou area

\begin{tabular}{|c|c|c|c|c|c|c|}
\hline \multirow{2}{*}{ Land use/cover units } & \multicolumn{6}{|c|}{ Years } \\
\cline { 2 - 7 } & \multicolumn{2}{|c|}{1972} & \multicolumn{2}{c|}{1986} & \multicolumn{2}{c|}{2001} \\
\cline { 2 - 7 } & Ha & $\%$ & Ha & $\%$ & Ha & $\%$ \\
\hline Continuous pluvial Culture / fallow & 178983.9 & 68,83 & 185690,5 & 71,41 & 185440,0 & 71,32 \\
\hline Grazing Area & 25008 & 9,61 & 20038,8 & 7,70 & 19577,7 & 7,52 \\
\hline Crops under wooded park & 18416.7 & 7,08 & 16217,3 & 6,23 & 14676,9 & 5,64 \\
\hline Shrub savannah & 11539.5 & 4,43 & 9327,2 & 3,58 & 9459 & 3,63 \\
\hline Raised savannah & 5387.3 & 2,07 & 4972,6 & 1,91 & 4397,8 & 1,69 \\
\hline Flooded area & 4052.7 & 1,55 & 3380,3 & 1,30 & 5482,5 & 2,10 \\
\hline Transhumance corridor & 4013.1 & 1,54 & 3655,4 & 1,40 & 3470,7 & 1,33 \\
\hline Crusted surface & 3104.2 & 1,19 & 5579,2 & 2,14 & 8781,6 & 3,37 \\
\hline Aquatic prairie & 2768.6 & 1,06 & 3042,2 & 1,17 & 1081,6 & 0,41 \\
\hline Bare plateau & 2739.9 & 1,05 & 4041,2 & 1,55 & 4521,0 & 1,73 \\
\hline Channels flow & 2531.7 & 0,97 & 2416,3 & 0,92 & 1493,2 & 0,57 \\
\hline Ponds/basins & 842.8 & 0,32 & 1022,4 & 0,39 & 1001,4 & 0,38 \\
\hline Stream bed & 611,6 & 0,23 & 616,6 & 0,23 & 616,6 & 0,23 \\
\hline TOTAL & 260000 & 100 & 260000 & 100 & 260000 & 100 \\
\hline
\end{tabular}

$\mathrm{a} / \mathrm{A}^{*} 100(\mathrm{a}=$ land use/cover unit area; $\mathrm{A}=$ Total area) 
Table 3. Land use/cover change between periods 1972, 1986 and 2001 in Waro-Souloulou area

\begin{tabular}{|c|c|c|c|c|c|c|}
\hline Land use/cover units & \multicolumn{3}{|c|}{ Absolute area cover in Ha } & \multicolumn{2}{c|}{ Cover change between periods in \% } \\
\hline & 1972 & 1986 & 2001 & $1972-2001$ & $1972-1986$ & $1986-2001$ \\
\hline Continuous Pluvial Culture / fallow & 178983,9 & 185690,5 & 185440 & 3.60 & 3.74 & -0.13 \\
\hline Grazing Area & 25008.0 & 20038,8 & 19577,8 & -21.71 & -19.87 & -2.3 \\
\hline Crops under Wooded park & 18416.7 & 16217,3 & 14676,9 & -20.30 & -11.94 & -9.49 \\
\hline Shrub savannah & 11539,5 & 9327,2 & 9459,0 & -18.02 & -19.17 & 1.41 \\
\hline Raised savannah & 5387,3 & 4972,6 & 4397,8 & -18.36 & -7.69 & -11.55 \\
\hline Flooded area & 4052,7 & 3380,3 & 5482,5 & 35.28 & -16.59 & 62.18 \\
\hline Transhumance corridor & 4013,1 & 3655,4 & 3470,7 & -13.51 & -8.91 & -5.05 \\
\hline Crusted surface & 3104,2 & 5579,2 & 8781,6 & 182.89 & 79.73 & 57.39 \\
\hline Aquatic prairie & 2768,6 & 3042,2 & 1081,6 & -60.93 & 9.88 & -64.44 \\
\hline Bare plateau & 2739,9 & 4041,2 & 4517 & 65 & 47.49 & 11.87 \\
\hline Channels flow & 2531,7 & 2416,3 & 1493,2 & -41.01 & -4.55 & -38.2 \\
\hline Ponds/basins & 842,8 & 1022,4 & 1001,4 & 18.81 & 21.3 & -2.05 \\
\hline Stream bed & 611,6 & 616,6 & 616,6 & 0.81 & 0.81 & 0 \\
\hline Total & 260000 & 260000 & 260000 & & & \\
\hline
\end{tabular}

F-I/I*100 (I= Initial year area; F = final year area); after Diress et al. (2010) 


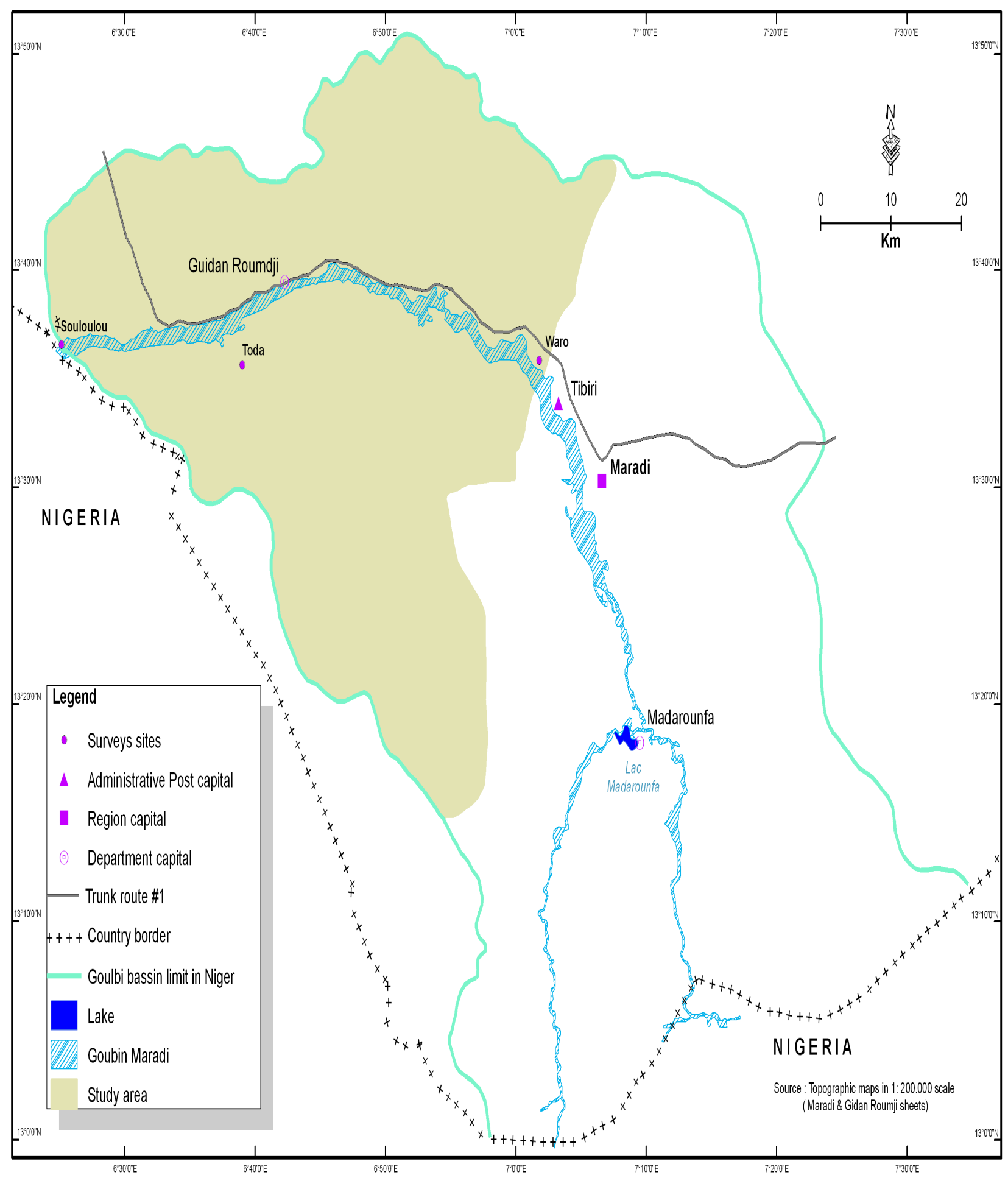

Figure 1. Study area location map 


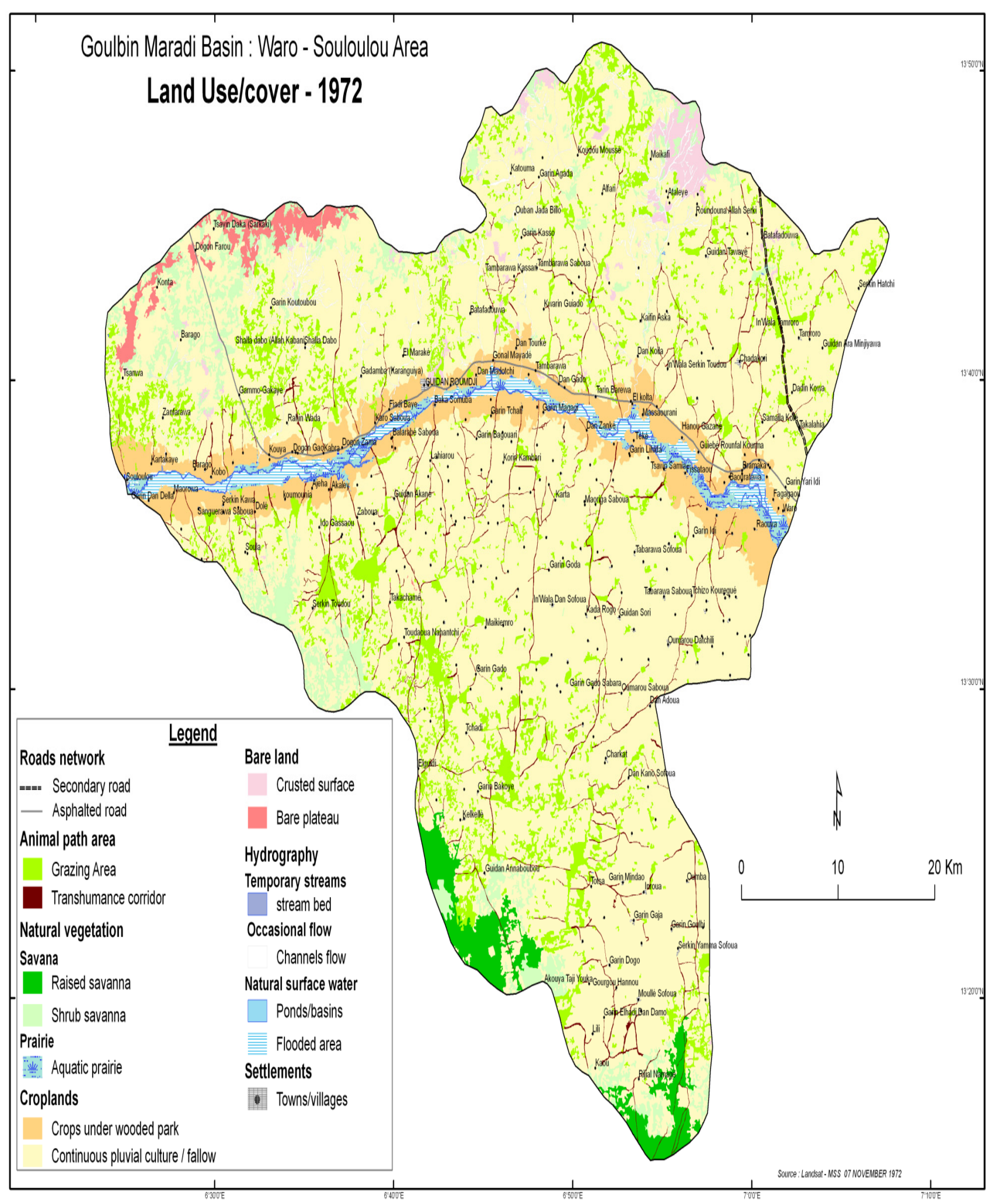

Figure 2. Land use/cover map in 1972 of goulbi Maradi watershed in Waro-Souloulou Area 


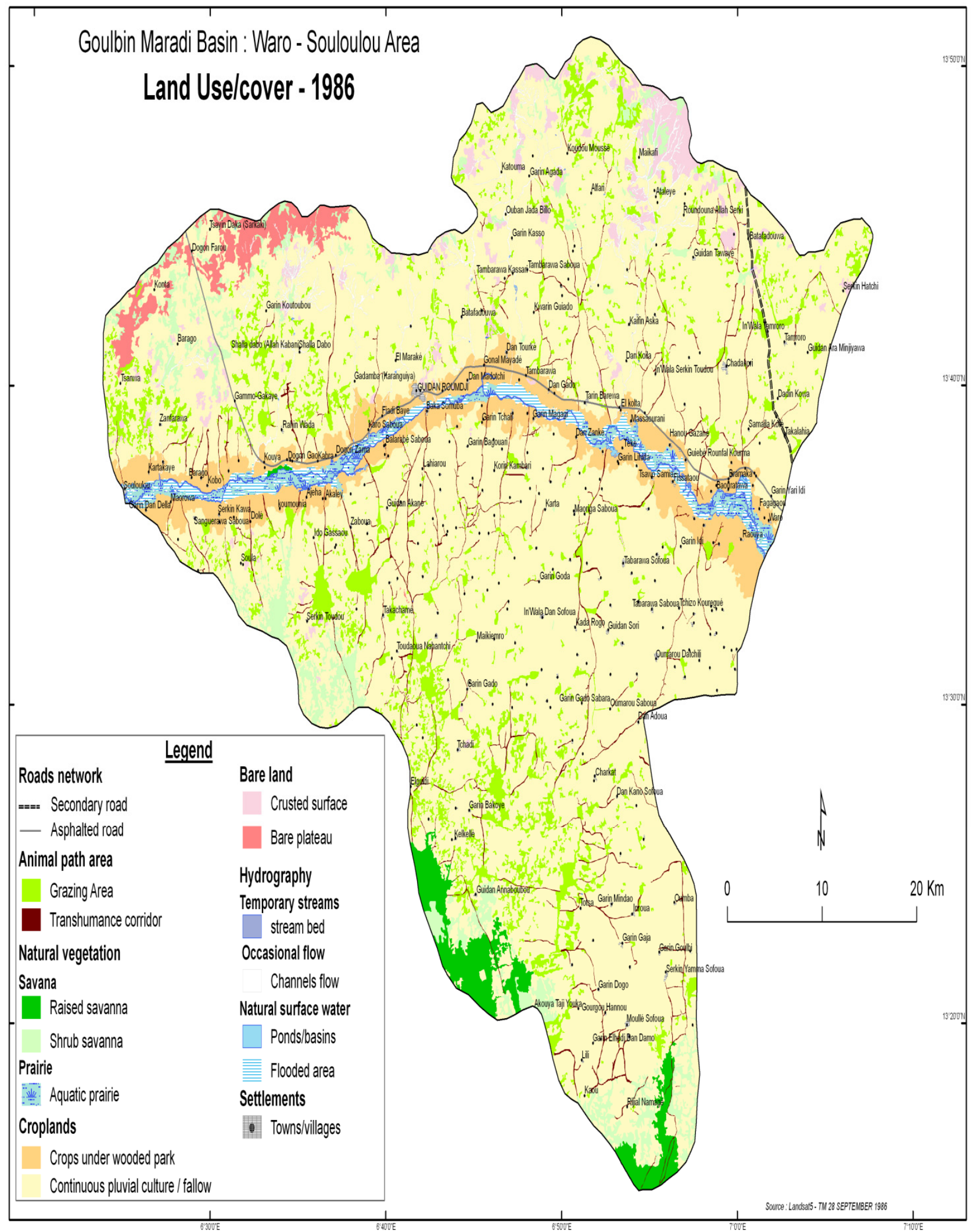

Figure 3. Land use/cover map in 1986 of goulbi Maradi watershed in Waro-Souloulou Area 


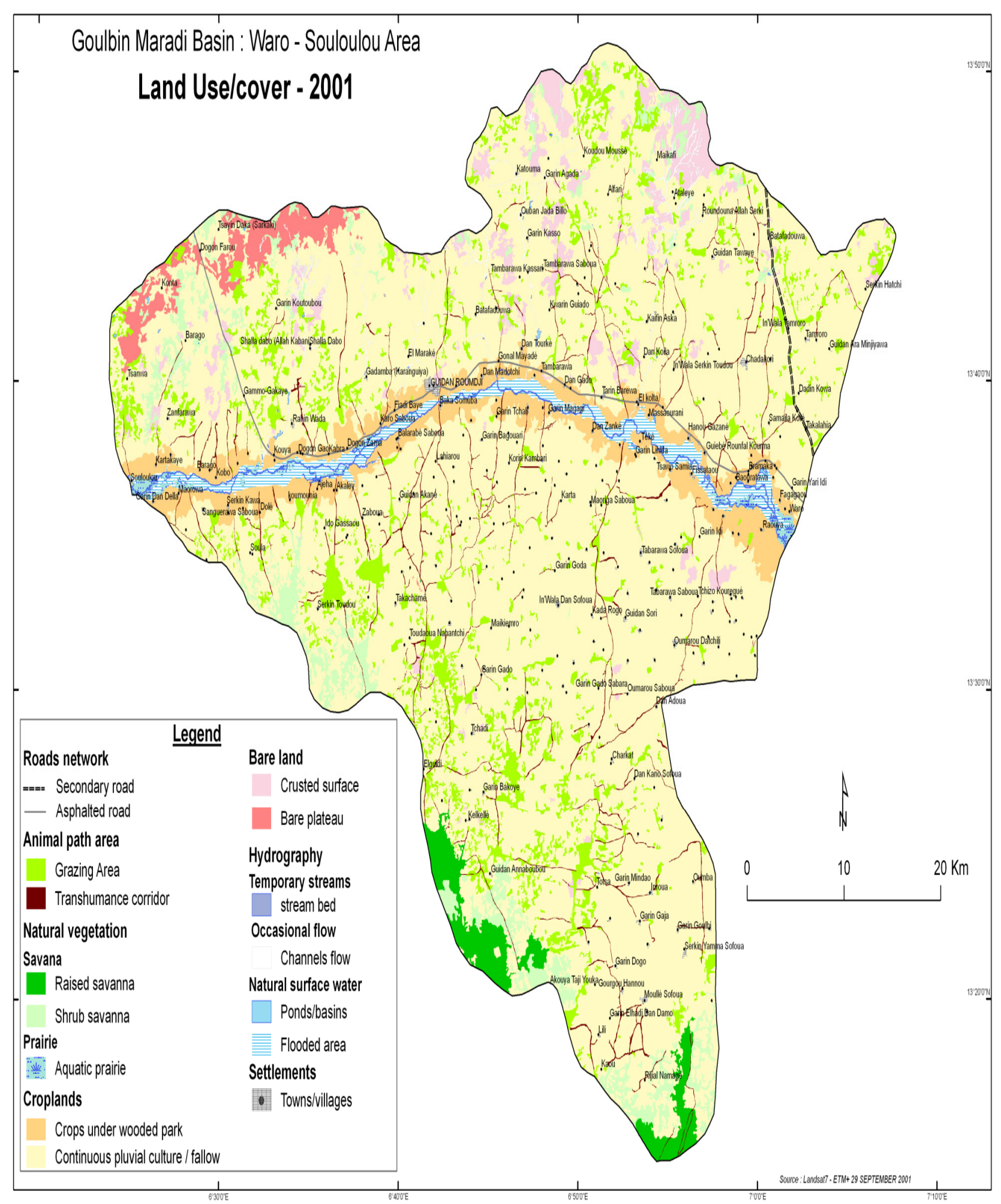

Figure 4. Land use/cover in 2001 map of goulbi Maradi watershed in Waro-Souloulou Area 


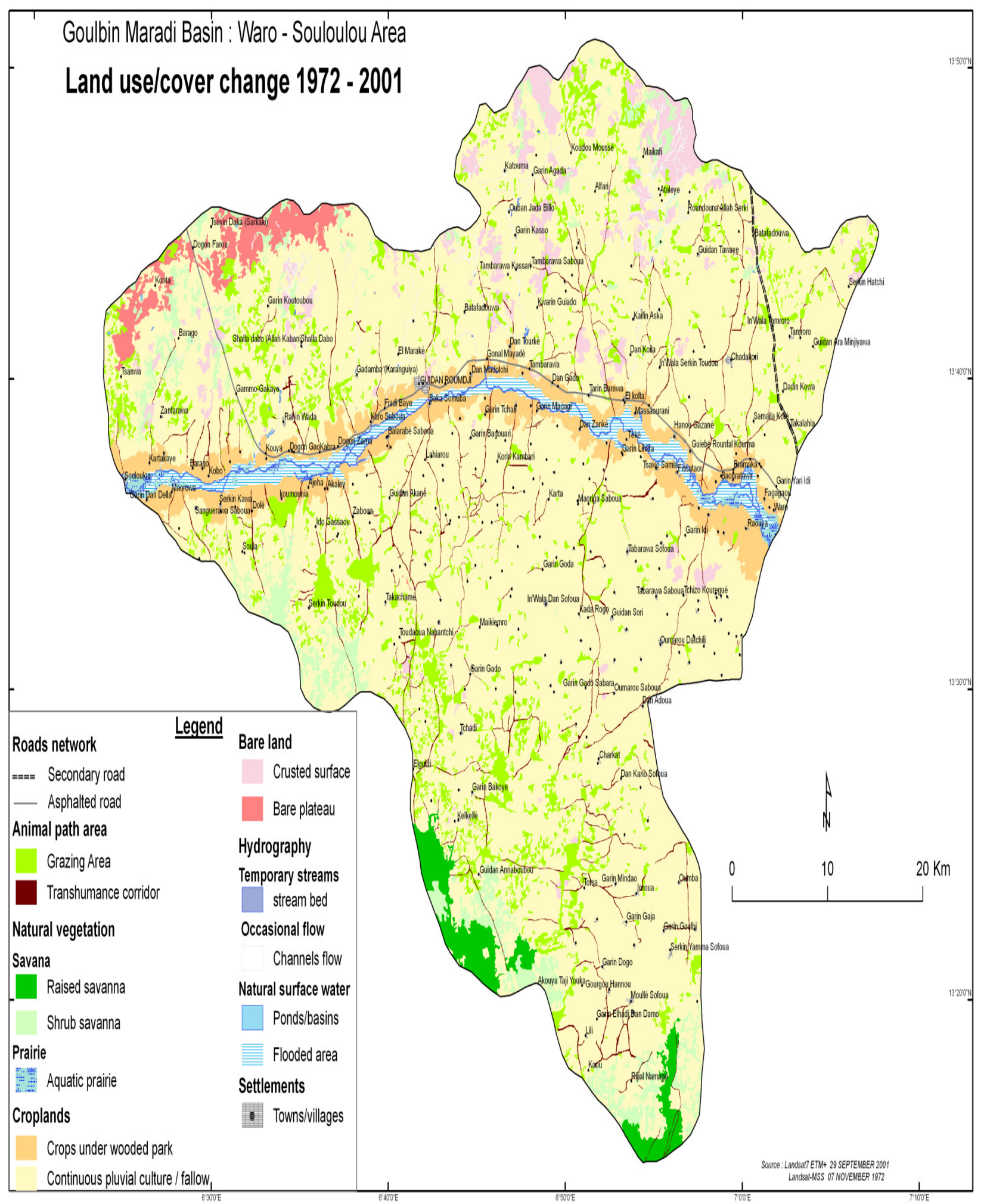

Figure 5. Land use/cover change map between 1972 and 2001 of goulbi Maradi watershed in Waro-Souloulou Area 